\title{
Action And Learning: Making Sense Of And Giving Meaning To. A Research On Enquiry Based Learning In An Applied Theatre Model
}

\author{
Marios Koukounaras-Liagkis \\ Lecturer in Religious Education at University of Athens, \\ Faculty and Department of Theology
}

Doi:10.5901/mjss.2013.v4n11p333

\begin{abstract}
This article presents the results of a three year research conducted by the author based on an educational project which was implemented in a Greek Secondary school for two years (2009-11). 'We organise a conference' was a project that presented students with an open-ended key evaluative question which they were required to answer. It was based upon enquiry based learning and it used the methods and techniques of applied theatre. Over the school year students researched an issue through role play (related to the process of organizing and taking part in a conference), which led to improvements in their cognitive skills while at the same time gaining greater insight into the issue and their own attitudes and practices. This is the educational way of 'making sense of' and 'giving meaning to' an issue related to students' lives. The author discusses the learning outcomes of the process and the educational importance and value of the method in the larger context of educational design. Empirical methods such as texts and by-products of the project, a research journal and semi-structured interviews, questionnaires and observation provided the basis for the hermeneutical analysis method which was used in the quantitative and qualitative survey, the findings and results of which are presented in the article.
\end{abstract}

\section{Introduction}

The fundamental purpose of this study was to answer the question of whether the effectiveness of a constructivist approach to learning based on action in the classroom could be measured or not. Although studies concerned with scaffolding an enquiry based learning process in science are common (Kirschner, Sweller \& Clark 2006, p. 75-6) in the Humanities and especially in the fields of Religious Education (hereafter RE) (Grimmitt, 2000; Stern, 2006; Erricker, 2010) and Applied Theatre (hereafter AT) (Etherton \& Prentki, 2006) there are few of them and they largely posed more questions about assessment and evaluation than answers. Moreover it is difficult to find such researches in the Greek educational context (Koukounaras-Liagkis, 2009) especially in the field of RE mainly owing to the lack of academic interest not only from Primary Education Faculties where the subject of RE is widely disparaged (in 9 Faculties RE does not exist as a compulsory subject although RE is a compulsory subject in 4 of the 6 years of Elementary Education) but also from the Faculties of Theology where educational research is limited.

The combination of pedagogy and experience of RE and AT posed a challenge for the author while at the same time providing a basic platform from which to conduct the research. Over a two-year period the learning process was studied whereby students researched an issue through the medium of role play. This was facilitated through the students organizing and taking part in a conference. Evaluation was made as to whether their actions led to improvements in the students' cognitive situation while at the same time gaining greater insight into the issue and their own attitudes and practices. This article summarizes the findings of the study and examines the implementation of the post-modern constructivist theory in everyday practice in education especially since most RE teachers in Greece have no experience of this approach.

\section{Context of the research}

\subsection{RE in Greece}

Although Greece is a secular state, the presence of the Eastern Orthodox Church established by the Greek constitution as the prevailing religion of Greece, has led to the institution of elements of legal agreements between the State and the Church in different areas. One such area is RE which is a subject contained within in the national curriculum of the school system. (The recent curriculum of 2011 is under a pilot scheme). 
Since the majority of the population belongs to the Orthodox Church, although the state does not keep a record of the numbers anymore concerning the religious landscape of religious believers or non believers, RE remains in practice and in content Orthodox Christian. The framework for RE in schools is provided by the basic Law for Education (1566/1985) which decrees that all students on a mandatory basis have to have been taught the 'authentic' tradition of the Orthodox Church (article 1, paragraph 1). At the same time article 13, paragraphs 1-2 of the Greek constitution guarantee the basic right to freedom of religion and associate it with the development of religious consciousness. As a consequence everyone has the right to be exempted from RE by making a statement arguing that his religious consciousness is offended by taking part in a RE class. Of course there are a number of Muslims in Greek schools which include migrants and the Muslim minorities in Thrace (a region in the northern part of Greece), together with minorities of other religions. The native Muslims who live in Thrace and are recognized as a minority according to the Lausanne Treaty (1923) are entitled to their own educational system which comprises 11.197 (2003) students and is based on a strictly confessional RE meaning that young Muslims study only the Holy Qur'an. It should be noted that many young Muslims in Thrace go to Greek public schools but there are no official statistics for them. Recently the Greek State amended a 2007 law which was never implemented and enacted a formal Muslim RE only for the schools of Thrace and for the students of the Minority who attend Greek public schools and have the right to withdraw from RE due to reasons relating to their religious consciousness (Amendment of Law 3536/2007-16 January 2013). This movement although it seems fair and friendly for the minority is controversial because at the same time the State has radically transformed the Curriculum of RE (2011) for Greek compulsory education aiming, theoretically at least, to have a non-confessional RE. Furthermore, among the migrant population there are not only Muslims but adherents of other religions. In 2007-8, 112.082 migrants were enrolled in Greek education from pre-school to secondary education including vocational. The migrants who accounted for $10 \%$ of the total number of students in schools during that period, numbered 1.208 .040 (I.PO.DE 2008) and were Albanian, Russian, Georgian and Bulgarian, comprising Christians and non-Christians. Thus RE as a compulsory subject, nowadays, is considered as an open-ended educational process that does fair justice to religious pluralism whilst providing religious literacy and supporting students in developing their cultural identity by teaching mainly Christian Orthodoxy and other religions (Yangazoglou, 2007). Despite the Orthodox content of RE only a few parents wish to withdraw their children from RE even though it is possible by law and historically this has been the case with Muslims and Jehovah's Witness parents in particular.

\subsection{Pedagogical context-a constructivist approach}

Constructivism is a meta-theoretical label that has been used in a wide variety of disciplines including pedagogy and education. In each discipline it has a different meaning so there would be no point in starting out with an all embracing definition of the concept. Firstly, one issue that needs to be addressed is that constructivism has moved away from trying to explain an objective reality. It should be considered more as a critique of realism, emphasizing that reality is constructed and contingent on the individual's standpoint. With reference to pedagogy and education, the theory identifies knowledge as a process of constructing subjective representations of reality, which is dependent on the way individuals and communities order the experience and interpret reality (Grimmitt, 2000, p. 208). This means that previous knowledge, beliefs and ideas are valued but at the same time all truth claims, even religious ones, are open to challenge (Erricker, 2010, p. 78).

In RE Grimmitt (2000) introduces a three-stage constructivist process which is based on the radical constructivism of von Glasersfeld (1995) since he argues that knowledge is 'exclusively an order and organization of a world constituted by our experience and not a reflection of an objective ontological reality' (Grimmitt, 2000, p.210). Thus knowledge is constructed by each student individually while the lesson engages students in enquiry rather than instruction and links their own experience to the religious content. Erricker (2010) places more emphasis on a conceptual basis for religious development through his work and research contextualizing a constructivist pedagogical model of 'conceptual enquiry in RE'.

In these respects a lesson focused upon the memorization of or learning facts and knowledge of which students can be certain, has no meaning (Dewey, 1902). On the contrary an enquiry based method of teaching which focuses upon enquiry as a way of making sense of, and giving meaning to the students' world is more worthwhile, hence students actively become experienced investigators of their reality and existence, seeking to answer questions and inquiring rather than validating certain objects of knowledge (Webster, 2009, p. 98-100)

On the other hand, AT often draws upon constructivism methodology as a way of bringing participants into direct engagement with their own learning experiences. Youngsters as learners bring a wealth of experiences and perspectives 
that further affect how they interact with a theatre/ drama- in -education experience in the classroom and how they respond to a variety of concepts, beliefs and practices within religions and their own cultural experience. An approach to RE using AT emphasises the development of skills and attitudes required to debate and deconstruct knowledge as well as to construct persuasive arguments. This means that the role of RE is to develop the capacity to interpret, evaluate different values and beliefs through the development of the students' analytical skills as well as their creative, imaginative and emotional capacities. AT facilitates interaction between students and religious content in classes or projects dealing with religion in a form of role play (a 'Mantle of the expert' technique) (Heathcote \& Bolton, 1995) which can constitute a safe space for students' experimenting with religious and non-religious world views. Moreover in AT a) drama involves the modelling of the reality of life and its complexities through the use of the dramatic medium, b) cultural identity can be seen as a personal narrative which is constantly extended and modified by many other narratives - global and local - and experiences to which we are exposed; The use of Drama/Theatre in education creates opportunities for participants to recognise how identity orientations (religion, nation, race, gender) shape their actions and positions and how irreversibly 'the other' has a central role in constructing the individual's identity and knowledge, c) by entering the fictional world created in the drama, a participant may gain greater understanding of his own, personal narrative. This is a major source of scientific claims that attitudes and behaviours can be changed; and d) providing a safe educational environment where the dramatic experience is not real so one can release oneself safely into it. This is also a dynamic key factor in attitude and behavioural change (Somers, 2004, p. 2).

\section{3 'We organize a conference' project}

The concept of the 'We organize a conference' project (WOCproj) incorporated the enquiry based method and a contextual dramatic enquiry approach named 'Mantle of the Expert' (Heathcote \& Bolton, 1995). Basically the approach is always contextual. Teacher and students create a context and they do all the work as if they are all a group of experts. In the 'Mantle of the Expert', there is always an enterprise to be run. So teacher and students share the responsibility for the enterprise, just as one would an enterprise in real-life, based on action and processes; therefore a context of learning is provided and at the same time the dramatic and inquiry learning medium helps students to develop ways of seeing through the eyes of others and develop ownership over their enterprise. Moreover they are motivated by the challenge of making their enterprise work. Of course classes do what the curriculum demands as they explore their learning and this brings special responsibilities, literacy needs and social behaviours.

In the WOCproj the enterprise was for the teacher and students to organize a scientific conference related to religion and issues contained in the curriculum of RE which matter to them personally. They were asked to agree, for the school year, to imagine themselves as groups of scientists, conference organizers and journalists. The project was part of the lesson and the classes had agreed from the start that every week one of the two hours of RE had to be dedicated to this enterprise. They followed the whole procedure of organizing a conference and at the end they actually held a conference. They found the idea and the goals of the conference, they made all the preparations concerning the location, time, programme, finances, technical support, they issued an official invitation for submitting applications, the evaluation of the abstracts (the teacher was the scientific committee) and finally the assessment of the event. The scientists and the journalists were the participants of the conference and the proceedings included their papers and articles (KoukounarasLiagkis, 2011, p. 153-158).

\section{The research}

\subsection{Research Facts}

The time line: September, 2009 - May, 2012

The location: A Greek Secondary Education School (Lyceum) located in Attica at Neo Iraklion (1 ${ }^{\text {st }}$ Lyceum of Neo Iraklion of Attica), which is an urban school with regard to socio-economic position and religious background and gender. The students were all Christians.

Sample: Students started the $1^{\text {st }}$ class of the Lyceum in 2009-10 and graduated in May of 2012. There was a fluctuation in the total number of participants every year (table 1 ) 


\begin{tabular}{|c|c|c|c|}
\hline $1^{\text {st }}$ LYCEUM of Neon Iraklion & $1^{\text {st }}$ class & $2^{\text {nd }}$ class & $3^{\text {rd }}$ class \\
\hline $2009-10$ & 124 & - & - \\
\hline $2010-11$ & - & 119 & - \\
\hline $2011-12$ & - & - & 118 \\
\hline
\end{tabular}

\section{Table 1}

\subsection{Hypothesis and research questions}

The research attempts to investigate the potential for the effectiveness of a constructivist action learning approach to RE according to its aims which were predicated upon a contextual dramatic enquiry method. Mainly the discussion broadened to investigate an intrinsic aspect of the existence of RE: whether students construct their own knowledge by making sense of and giving meaning to their world when they study issues of RE. Other questions were raised related to the subject and its issues and to pedagogical techniques but these are not analysed in this paper.

The projects had the following topics and aims regarding RE:

Topic of 2009-10: 'The position of the laity and women in Christianity'

Aims: To help young people

to consider the contribution and the role of the laity, and especially of women in Christian communities throughout the centuries and the current situation concerning them.

to investigate feminist theology and other modern approaches to Religious studies

to understand how Christian believers act as members of their communities and follow the requirements of their beliefs and traditions.

to evaluate their ideas and positions about contemporary parishes.

Topic of 2010-11: 'We and the world's religions'

Aims: To help young people Taoism)

to survey the beliefs and traditions of different religions of the world (Islam, Judaism, Buddhism, Hinduism,

to discover aspects, symbols and elements in their lives from a variety of religions and world views regardless of having a religion or not.

to realize that religions affect the world, ethnicities, countries and students themselves, in some cases imperceptibly.

to evaluate the dialogue on religious issues as an important mean of understanding others as well as the current events going on in the world

to explain significant examples of how their response to the concepts of religious aspects would affect their own lives and those of others.

The projects for both of the school years had the following aims regarding pedagogy:

to support students by asking and defining questions, debating ideas, making predictions, designing plans, collecting and analyzing data, drawing conclusions, presenting their ideas and creating posters, badges, etc.

to develop students' thinking and critical skills and their creative, imaginative and emotional development.

to develop their capacities to interpret, evaluate and respond to different beliefs and values.

to foster mutual understanding between themselves regardless of their cultural and religious backgrounds.

to improve their communication and interpersonal/social skills

to engage the students in investigation and to take active roles in their learning process

to encourage them to take full responsibility for their learning and so to construct their own attitudes toward it.

\subsection{Methodology}

The research was an educational qualitative research with a quantitative component using empirical methods and hermeneutical methods for text analysis. The research tools were:

Observation of the groups during the entire process of their research, creation and presentation of their projects.

Written questionnaires (2) were filled in anonymously in two stages: September and May of each school year

Recorded semi-structured interviews (3) with randomly selected students, before, during and after the application of the project. 
Journals were kept by the RE teacher throughout the process

Observation of the students' responses during the application of the project by videotaping for interaction analysis.

The data was analyzed using the SPSS (Statistic Package for Social Science) due to the need for simultaneous processing and depiction both of qualitative and quantitative variables. The written and oral material (questionnaires, journal, semi-structured interviews, observations) were analyzed by hermeneutical critical content analysis.

\section{Presentation of the results}

After two years $88 \%$ of the students stated that participation in preparing the conference project had led to them learning more about religion than they had with other teaching methods applied by the same teacher during the two years of the research and the three previous years in Gymnasium.

"I learned about different religions and my own and now I recognise that many things and problems in my life are related to them'- 'I never believed that I could have such an interest in religious topics'- 'Religion is a part of our everyday life. We have to be active even if we are not very religious. Maybe with our actions things will get better in the religious communities and for all the others who are affected by their activities'.

These are some representative students' comments about the outcomes of the project. Moreover there is a $3 \%$, with correlation $(\mathrm{p}<0.001)$ between it and gender (they are all males), who stated that they had problems investigating different religions to their own.

The questionnaires before and after the conferences revealed that there is a significant difference in the answers after the implementation of the project and that defines the value it has for RE (Table 2 and Table 3). Furthermore the majority of the students admitted that after the two projects they found religious issues interesting (78\%), that RE helped them to understand current issues (68\%), to learn about themselves (72\%), to learn about their religion-even if the project was for other religions (77\%). It is worth noting that the students did not seem to have a problem expressing their views about religion openly in school (90\%-100\%). Finally, the two tables indicate that after the first year the majority of the group had changed their opinion about RE by the start of the second year.

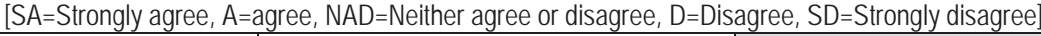

\begin{tabular}{|l|c|c|c|c|c|c|c|c|c|c|}
\hline & \multicolumn{5}{|c|}{ Before } & \multicolumn{7}{|c|}{ After } \\
\hline $\mathbf{2 0 0 9 - 1 0 ~ n = 1 2 4 ~}$ & SA & A & NAD & D & SD & SA & A & NAD & D & SD \\
\hline I find religious issues interesting & 9 & 26 & 23 & 28 & 13 & 18 & 39 & 17 & 10 & 16 \\
\hline $\begin{array}{l}\text { Learning about religion helps me } \\
\text { to understand current issues }\end{array}$ & 4 & 23 & 44 & 21 & 8 & 14 & 28 & 32 & 20 & 6 \\
\hline $\begin{array}{l}\text { Learning about religion helps me } \\
\text { to learn about myself }\end{array}$ & 10 & 13 & 41 & 26 & 20 & 22 & 30 & 19 & 20 & 9 \\
\hline $\begin{array}{l}\text { Learning about religion helps me } \\
\text { to learn about my religion }\end{array}$ & 21 & 22 & 35 & 17 & 5 & 42 & 36 & 12 & 10 & 0 \\
\hline $\begin{array}{l}\text { I am uncomfortable with sharing } \\
\text { my views about religion openly } \\
\text { in front of all }\end{array}$ & 5 & 9 & 26 & 32 & 28 & 2 & 2 & 6 & 17 & 73 \\
\hline
\end{tabular}

Table 2

\begin{tabular}{|c|c|c|c|c|c|c|c|c|c|c|}
\hline & \multicolumn{5}{|c|}{ Before } & \multicolumn{5}{|c|}{ After } \\
\hline $2010-11$ & SA & A & NAD & $\mathrm{D}$ & SD & SA & A & NAD & $\mathrm{D}$ & SD \\
\hline I find religious issues interesting & 16 & 36 & 22 & 16 & 10 & 48 & 30 & 22 & 0 & 0 \\
\hline $\begin{array}{l}\text { Learning about religion helps me to understand } \\
\text { current issues }\end{array}$ & 8 & 26 & 49 & 10 & 7 & 32 & 36 & 22 & 10 & 0 \\
\hline $\begin{array}{l}\text { Learning about religion helps me to learn about } \\
\text { myself }\end{array}$ & 20 & 28 & 20 & 22 & 10 & 32 & 40 & 18 & 8 & 2 \\
\hline $\begin{array}{l}\text { Learning about religion helps me to learn about } \\
\text { my religion }\end{array}$ & 29 & 42 & 19 & 10 & 0 & 23 & 54 & 11 & 10 & 2 \\
\hline $\begin{array}{l}\text { I am uncomfortable with sharing my views about } \\
\text { religion openly in front of everyone. }\end{array}$ & 0 & 8 & 12 & 14 & 66 & 0 & 0 & 0 & 16 & 84 \\
\hline
\end{tabular}

Table 3 
In the final exams the number of the students who reached the targets and cognitive aims were significant as Table 4 shows. Moreover, the comparison between the grades in RE and other similar subjects of the Curriculum (History and Literature) defines the importance of the choice of learning and teaching method for all students.

\section{Table 4}

\begin{tabular}{|c|c|c|c|c|}
\hline Grades & $2009-10$ & $n=124$ & $2010-11$ & $n=119$ \\
\hline Excellent $(18,1-20)$ & 90 & $72,5 \%$ & 91 & $76,4 \%$ \\
\hline Very good (16,1-18) & 19 & $15,3 \%$ & 15 & $12,6 \%$ \\
\hline Good (13,1-16) & 11 & $8,8 \%$ & 13 & $10,9 \%$ \\
\hline Nearly good (9,5-13) & 4 & $3,2 \%$ & 0 & $0,0 \%$ \\
\hline Failed $(0-9,5)$ & 0 & $0.0 \%$ & 0 & $0,0 \%$ \\
\hline
\end{tabular}

Concerning the statement 'I find religious issues interesting' there are significant correlations $(p<0.001)$ to those who stated that through the WOCproj they learnt a lot (67\%). Moreover the majority admitted that in their role they felt responsible (91\%), they were co-operative (59\%), they were creative $(62 \%)$, they were known each other $(78 \%)$, they felt safe $(78 \%)$ they felt satisfied as a member of a team (82\%), they felt confidence (56\%). Above all the students noted that they wanted all the subjects of the curriculum to be taught by action learning (88\%).

Finally, the data interpretation and the comparison with the data of the qualitative study indicates that the majority of the students agree that they learnt to have respect for everyone regardless of their religious beliefs or non-beliefs because they had discussed all religions from different perspectives at school.

\section{Conclusion}

The research illustrates that an action learning project based on the contextual dramatic enquiry method firstly effectively helps students to learn to work in a community, thereby taking on social responsibilities. Additionally, when students take responsibility for their learning, their self-esteem soars and they feel confident in creating better work habits and attitudes toward learning. Of course the final tests revealed that students had been able to raise their testing grades by implementing the project. Students also learn cognitive and meta-cognitive skills that are essential in their education and generally in their lives. Most important of all, students effectively refined their understandings of concepts, phenomena and issues with their own knowledge building. It is truism to say that if the project does not remain true to its original plan and is not content driven, the student will not have a successful learning outcome. Benefit is only derived when it is applied successfully. Finally, what cannot be concluded with any certainty and answered in a definite way is the duration of cognitive and meta-cognitive effectiveness and that is the reason findings about tolerance and openness are not mentioned even though they were measured.

The findings, however, of the analysis suggest that for the vast majority of students thinking and talking about religion is worthwhile. They agree that when they learn about different religions and at the same time their own religion, they learn to respect the 'others'. They also believe that RE helps them to understand and interpret current issues and, more importantly, that school is a safe place to openly discuss religious topics.

To summarise the overall conclusion of the data analysis on the role of RE in the curriculum, it is important to stress that religion and knowledge of it seems to be widely considered a positive factor and an essential aspect of the students' education and their lives in general. As school is a place of learning it should provide not only knowledge about religions but allow students to develop the ability to communicate about different religions. It is a place where students should not merely be introduced to one specific religion but to gain a deeper insight into other religions, to re-think their ideas and preconceptions and to justify their own beliefs and values.

\section{References}

Dewey, J. (1902). The Child and the Curriculum. Chicago: University of Chicago Press.

Erricker, C. (2010). Religious Education. London, New York: Routledge.

Etherton, M. \& Prentki, T. (2006). Drama for change? Prove it! Impact Assessment in Applied Theatre. Research in Drama, Special Issue: Impact Assessment and Applied Drama. 11(2), pp. 139-155.

Glasersfeld E. von. (1995). Radical constructivism: A way of knowing and learning. London: Falmer Press.

Grimmitt, M. (Eds). (2000). Pedagogies of Religious Education. Essex: McRimmons.

Heathcote, D. \& Bolton, G. (1995). Drama for learning: Dorothy's Heathcote's mantle of the expert approach to education. Portsmouth, 
$\mathrm{NH}$ : Heinemann.


countries of former Soviet Union]. Retrieved from http://www.antigone.gr/en/stats/files/081101.pdf

Kirschner, P.A., Sweller, J., Clark, R.E. (2006). Why minimal guidance during instruction does not work: an analysis of the failure of constructivist, discovery, problem-based, experiential, and inquiry-based teaching. Educational Psychologist, 41 (2), 75-86.

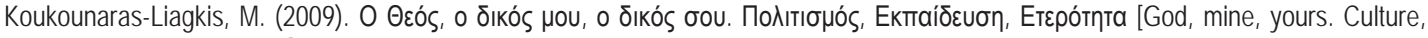
Education, Diversity]. Athens: Grigori.

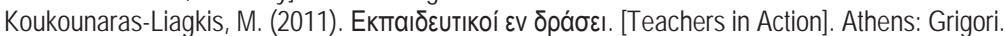

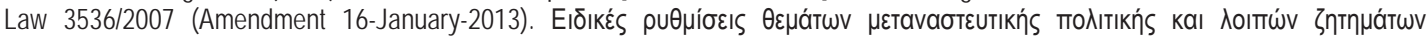

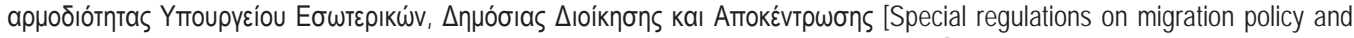
other issues concerning the Ministry of Interior, Public Administration and Decentralization].

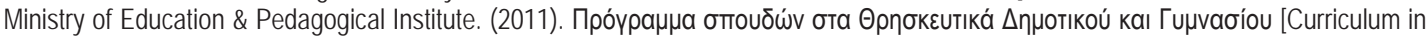
RE for Primary and Secondary Education]. Retrieved from http://digitalschool.minedu.gov.gr/info/newps.php

Somers, J. (2004). Drama as alternative pedagogy and its relationship with performance. Paper delivered in Hungary at the HUDEA National Conference, 20 November 2004. (Unpublished)

Stern, J. (2006). Teaching Religious Education. London, New York: Continuum.

Webster, R.S. (2009). The Educative Value of Dewey's Religious Attitude for Spirituality. International Journal of Children's Spirituality, 14(2), 93-103.

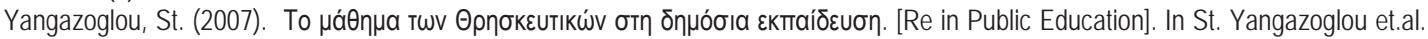

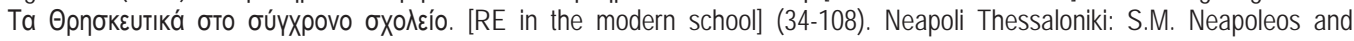
Stavroupoleos. 